\title{
The Relationship between Quality of Sleep and Geographical Directions during Sleeping Process
}

\author{
S. Mohamad Moosavi ${ }^{1}$, Mahshid Ahmadi ${ }^{2}$, Javad Setareh ${ }^{3}$, Mani B.Monajemi ${ }^{4}$
}

\section{ABSTRACT}

Objectives: Sleep has been one of God's most precious blessings since human's existence and it is vital for both body and soul. External and internal factors like age, sex, drug, illness, psychological pressure, job, life style and Earth's magnetic field influence quality of sleep drastically. In this study we tended to find the relationship between geographical direction during sleeping process and quality of sleep.

Methods: In a cross-sectional descriptive study, 200 students from university of Iran, Mazandaran province were selected arbitrarily. After exclusion, based on exclusion criteria, the number of research's samples reached to 153. Tools used regarding collecting data were standard Pittsburg sleep quality inventory (PSQI) in order to assess the quality of the sleep. Symptom Checklist-90-Revised (SCL- 90-R) was used in order to study psychiatric symptoms and an anonymous demographic questionnaire was used to record personal information, filled by individuals. Software Spss17 with chi-square were used for statistical analysis procedure.

Results: $30.7 \%(47$ cases) slept in north-south direction, 22.8\%(35) in south north, 26.2\%(40) in east west and 20.3\%(31) in west east. Among PSQI sleep scales, there was a strong relationship between difficulties in falling asleep with geographical directions of sleep $(\mathrm{p}<0.001)$. No significant relationship between sleep directions and other scales has been found.

Conclusion: Considering the high prevalence of sleep difficulties and strong relationship between geographical directions and quality of sleep. With respect to this study, sleep in northsouth position can be advised to improve sleep quality and it necessary in order to maintain sleep hygiene.

Keywords: Geographical sleep directions - PSQI- Quality of sleep

${ }^{1}$ Department of Psychiatry, Mazandaran University of Medical Science. Medical College. Sari. Iran.

${ }^{2}$ Depattment of Communication Medicine, Mazadaran University of Medical Science,Medical College. Sari, Iran

${ }^{3}$ Department of Psychiatry, Mazandaran University of Medical Science. Medical College. Sari. Iran.

${ }^{4}$ Department of Psychology and Mental Health Sciences, Tehran University of Medical Sciences. Tehran, Iran,

(C) 2015 I S Moosavi, M Ahmadi, J Setareh, M Monajemi; licensee IJIP. This is an Open Access Research distributed under the terms of the Creative Commons Attribution License (http://creativecommons.org/licenses/by/2.0), which permits unrestricted use, distribution, and reproduction in any Medium, provided the original work is properly cited. 
As long as human existence, sleep and the nature of its intriguing process has been a mystery. The duration and quality of sleep is under the influence of external and internal factors like age, sex, drugs, disease, physical, psychological and social factors. There are some other factors like job, life events and earth's magnetic field, which can affect sleep quality and its recurrence (1). Although sleep appears to be a passive and restful time, it actually involves a highly active and well-scripted interplay of brain circuits, resulting in sleep's various stages.

(2) Sleep deprivation may affect cognition, behavior and speech. (3). Sleep disturbance may be part of many psychiatric disorders (4). Hormonal changes during menstrual cycle, pregnancy and menopause can be influential on sleeping process (5). Drop of sleep is one of the most prevalent complaints (6). Dysomnias are disturbing phenomenon arising in $3^{\text {rd }}$ and $4^{\text {th }}$ stages of sleep (7). Earth's magnetic field is one of the environmental reasons, which affect sleeping quality (8). Sometimes migration of some species of birds and animals completely depends on the earth's magnetic field (9). Interactions between sunlight and earth's magnetic field may be also effective (10). The effect of the magnetic field on REM Latency has been widely studied (11). There are only few studies about earth's magnetic field and the quality of sleep in the academic literatures. That's why this study is considered to be one of the few studies that had been conducted in this area. The question that we intended to answer was as follow: Is there any relationship between sleep quality and geographical directions during sleep?

\section{MATERIALS AND METHODS}

In this cross-sectional descriptive study, 200 undergraduate students in Iran, Mazandaran province were selected randomly in order to determine the relationship between geographical directions during sleep and sleep quality. After exclusion, based on exclusion criteria, the number of research's samples reached to 153. Exclusion criteria of cases were those who during previous month of the study: experienced major physical disorder, consumption of sleeping/Psychiatrics drugs, OTC (over the counter) drugs, pregnant or breast-feeder and had no diagnosed psychiatric disorder and the diagnosis of former group was based on scale of Symptoms Checklist-90-Revised (SCL-90-R). Psychological pressures caused by the exam as confounding variable excluded by doing the study in the non-exam season. Pittsburg sleep quality inventory (PSQI) and SCL- 90- R and also an anonymous questionnaire for demographic information were given to examinees and themselves completed them after explanation about the research process and obtaining an informed consent. Those who participated in this study did not have major change in their living location and geographical direction of sleep previous month of the study. The direction was head to foot. If someone's head was toward north and his feet toward south, it was considered to be North-South and so on. Sub groups were categorized with regard to the closeness to one of the main direction. PSQI assesses the attitude toward quality of sleep, included the time when individuals tend to go to bed, awakening time, drop off, the duration of a good sleep, general self description of sleep and the amount of daily drowsiness (12) . In Iran, Tehran psychiatry institute assessed the validity and reliability of the Farsi version of this questionnaire with $89.6 \%$ for sensitivity and $86.5 \%$ for specificity (13). The sum of the 
grades have been $0-21$ and cutting point was 5 , means higher scores shows bad quality of sleep (14).

SCL- 90-R includes 90 questions for psychiatric symptoms assessment. Introduced by lipman and cuvay in 1973, it has scales in the field of physical complaints, obsession-compulsion, mutual relations, depression, anxiety, aggression, phobia, paranoia and psychosis (15). In Iran, Noorbala, Yazdi and his colleagues examined and confirmed the validity and reliability of SCL90-R (16). Data assessed by $\mathrm{X}^{2}$ test and analyzed by using SPSS16 software and ANOVA methods.

\section{RESULTS}

According to demographic questionnaire and based on exclusion criteria to remove some confounding variables, those who experienced prominent physical disorder (14 samples), hypnotic or psychiatric drug consumption (16 samples), over the counter drug consumption (10 samples), pregnant or breast-feeder were excluded. All samples were chosen from undergraduate students in order to remove job as confounding factor. Total average of age was 22.9 \pm 1.1 , the average age of females $22.3 \pm 1.4$ years, the average age of males $23.1 \pm 1 / 2$ years. No significant age difference was found $(\mathrm{P}>0.05)$. The distribution of geographical direction during sleep and the comparison according to subscales of PSQI is shown in tables 1-8. Except "difficulty falling sleep” no significant relationship between geographical directions with other scales observed.

Table No 1: Geographical direction of sleep

\begin{tabular}{|r|r|r|}
\hline Direction & Number & Percent \\
\hline N-S $\dagger$ & 47 & $\mathbf{3 0 . 7}$ \\
\hline S-N $\ddagger$ & 35 & $\mathbf{2 2 / 8}$ \\
\hline E-W§ & 40 & $\mathbf{2 6} / \mathbf{2}$ \\
\hline W-E || & 31 & $\mathbf{2 0} / \mathbf{3}$ \\
\hline \hline Total & $\mathbf{1 5 3}$ & $\mathbf{1 0 0}$ \\
\hline
\end{tabular}

† North-south, ₹ South-north, § East-west, II West-east

Table No 2: Comparison the time to go bed scale with geographical direction

\begin{tabular}{|c|c|c|c|c|c|c|c|c|}
\hline \multirow{2}{*}{$\begin{array}{r}\text { Directio } \\
n\end{array}$} & \multicolumn{2}{|c|}{ Night. 9-10 } & \multicolumn{2}{|c|}{ Night .11-12 } & \multicolumn{2}{|c|}{ Night .1-2 } & \multicolumn{2}{|c|}{ Night after 2} \\
\hline & $\begin{array}{r}\text { Numbe } \\
r\end{array}$ & $\begin{array}{r}\text { Perce } \\
\text { nt }\end{array}$ & Number & $\begin{array}{r}\text { Perce } \\
\text { nt }\end{array}$ & Number & $\begin{array}{r}\text { Perce } \\
\text { nt }\end{array}$ & Number & $\begin{array}{r}\text { Perce } \\
\text { nt }\end{array}$ \\
\hline $\mathrm{N}-\mathrm{S}$ & 5 & $10 / 6$ & 29 & $61 / 7$ & 7 & $14 / 9$ & 6 & $12 / 8$ \\
\hline S-N & 5 & $14 / 2$ & 18 & $51 / 4$ & 6 & $17 / 2$ & 6 & $17 / 2$ \\
\hline E-W & 6 & 15 & 13 & $32 / 5$ & 10 & 25 & 11 & $27 / 5$ \\
\hline W-E & 3 & $9 / 7$ & 9 & 29 & 9 & 29 & 10 & $32 / 3$ \\
\hline Total & 19 & $\overline{~(12.42)}$ & $\begin{array}{r}69(45.10 \\
\%)\end{array}$ & & $\begin{array}{r}32(20.92 \\
\%)\end{array}$ & & $\begin{array}{r}33(21.57 \\
\%)\end{array}$ & \\
\hline
\end{tabular}

$P>0 / 05 \quad X^{2}=14.88$ 
The Relationship between Quality of Sleep and Geographical Directions during Sleeping Process

Table No 3: Comparison the length of time to sleep scale with geographical direction

\begin{tabular}{|r|r|r|r|r|r|r|r|r|}
\hline \multirow{2}{*}{ Direction } & \multicolumn{2}{|c|}{$\mathbf{1 0 - 1 5}$ Min } & \multicolumn{2}{|c|}{ 15-30 Min } & \multicolumn{2}{|c|}{ 30-60 Min } & \multicolumn{2}{|c|}{ More than 1 hour } \\
\cline { 2 - 9 } & Number & Percent & Number & Percent & Number & Percent & Number & Percent \\
\hline N-S & 29 & $61 / 7$ & 12 & $25 / 5$ & 3 & $6 / 4$ & 3 & $\mathbf{6 / 4}$ \\
\hline S-N & 20 & $57 / 2$ & 9 & $25 / 7$ & 4 & $11 / 4$ & 2 & $5 / 7$ \\
\hline E-W & 20 & 50 & 8 & 20 & 6 & 15 & 6 & $\mathbf{1 5}$ \\
\hline W-E & 16 & $51 / 6$ & 8 & $25 / 8$ & 4 & $12 / 9$ & 3 & $\mathbf{9} 7$ \\
\hline \hline Total & $85(55.56$ & & $37(24.18$ & & $17(11.11$ & & $14(9.15$ & \\
& $\%)$ & & $\%)$ & & $\%)$ & & $\%)$ & \\
\hline
\end{tabular}

$\mathrm{P}>0 / 05 \quad \mathrm{X}^{2}=4.9$

Table No 4: Comparison the awakening time with geographical direction

\begin{tabular}{|r|r|r|r|r|r|r|r|r|}
\hline $\begin{array}{r}\text { Directi } \\
\text { on }\end{array}$ & \multicolumn{2}{|c|}{ Morning 5-6 } & \multicolumn{2}{|c|}{ Morning 6-7 } & \multicolumn{2}{|c|}{ Morning 7-8 } & \multicolumn{2}{|c|}{ Morning 9-10 } \\
\cline { 2 - 9 } & Number & $\begin{array}{r}\text { Perce } \\
\text { nt }\end{array}$ & Number & $\begin{array}{r}\text { Perce } \\
\text { nt }\end{array}$ & Number & $\begin{array}{r}\text { Perce } \\
\text { nt }\end{array}$ & $\begin{array}{r}\text { Number } \\
\text { atnecreP } \\
\text { seg }\end{array}$ \\
\hline N-S & 5 & $10 / 5$ & 12 & $25 / 5$ & 23 & 49 & 7 & $\mathbf{1 5}$ \\
\hline S-N & 7 & 20 & 8 & $22 / 8$ & 15 & $42 / 8$ & 5 & $\mathbf{1 4 / 4}$ \\
\hline E-W & 4 & 10 & 8 & 20 & 16 & 40 & 12 & $\mathbf{3 0}$ \\
\hline W-E & 5 & $16 / 2$ & 8 & $25 / 8$ & 10 & $32 / 2$ & 8 & $\mathbf{2 8 / 8}$ \\
\hline \hline Total & $\mathbf{2 2 ( 1 7 . 3 8}$ & & $\mathbf{3 6}(\mathbf{2 3 . 5 3}$ & & $\mathbf{6 4 ( 4 1 . 8 3}$ & & $\mathbf{3 2 ( 2 0 . 9 2}$ & \\
& $\%)$ & & $\%)$ & & $\%)$ & & $\%)$ & \\
\hline
\end{tabular}

$\mathrm{P}>0 / 05 \quad \mathrm{X}^{2}=6.93$

Table No 5: Comparison the real night sleep with geographical direction

\begin{tabular}{|c|c|c|c|c|c|c|c|c|}
\hline \multirow{2}{*}{$\begin{array}{r}\text { Directio } \\
n\end{array}$} & \multicolumn{2}{|c|}{ 4-5 hours } & \multicolumn{2}{|c|}{ 5-6 hours } & \multicolumn{2}{|c|}{ 6-7 hours } & \multicolumn{2}{|c|}{ More than 7 hours } \\
\hline & Number & Percent & Number & Percent & Number & Percent & Number & Percent \\
\hline N-S & 3 & $6 / 4$ & 13 & $27 / 6$ & 28 & $59 / 6$ & 3 & $6 / 4$ \\
\hline S-N & 3 & $8 / 6$ & 15 & $42 / 8$ & 12 & $34 / 3$ & 5 & $14 / 3$ \\
\hline E-W & 5 & $12 / 5$ & 16 & 40 & 15 & $37 / 5$ & 4 & 10 \\
\hline W-E & 5 & $16 / 1$ & 12 & $38 / 7$ & 12 & $38 / 7$ & 2 & $6 / 5$ \\
\hline Total & $\begin{array}{r}16(10.46 \\
\%)\end{array}$ & & $\begin{array}{r}56(36.6 \\
\%)\end{array}$ & & $\begin{array}{r}67(43.79 \\
\%)\end{array}$ & & $\begin{array}{r}14(9.15 \\
\%)\end{array}$ & \\
\hline
\end{tabular}

$\mathrm{P}>0 / 05 \quad \mathrm{X}^{2}=9.09$ 
Table No 6: Comparison the difficulty falling asleep with geographical direction

\begin{tabular}{|c|c|c|c|c|c|c|c|c|}
\hline \multirow[t]{2}{*}{ Direction } & \multicolumn{2}{|r|}{$0=$ None } & \multicolumn{2}{|c|}{$1=<1 /$ week } & \multicolumn{2}{|c|}{$2=1-2 /$ week } & \multicolumn{2}{|c|}{$3=>3 /$ week } \\
\hline & Number & Percent & Number & Percent & Number & Percent & Number & Percent \\
\hline N-S & 5 & $10 / 6$ & 24 & $51 / 1$ & 14 & $29 / 8$ & 4 & $8 / 5$ \\
\hline $\mathbf{S}-\mathbf{N}$ & 11 & $31 / 5$ & 13 & 37 & 7 & 20 & 4 & $11 / 5$ \\
\hline E-W & 9 & $22 / 5$ & 10 & 25 & 10 & 25 & 11 & $27 / 5$ \\
\hline W-E & 7 & $22 / 6$ & 7 & $22 / 6$ & 8 & $25 / 8$ & 9 & 29 \\
\hline Total & $\begin{array}{r}32(20.92 \\
\%)\end{array}$ & & $\begin{array}{r}54(35.29 \\
\%)\end{array}$ & & $\begin{array}{r}39(25.49 \\
\%)\end{array}$ & & $\begin{array}{r}28(18.3 \\
\%)\end{array}$ & \\
\hline
\end{tabular}

$\mathbf{P}<0.001 \quad X^{2}=16.92$ d.f $=9$

Table No 7: comparison the quality of sleep with geographical direction

\begin{tabular}{|c|c|c|c|c|c|c|c|c|}
\hline \multirow{2}{*}{$\begin{array}{r}\text { Directio } \\
\mathbf{n}\end{array}$} & \multicolumn{2}{|c|}{ Very good $=0$} & \multicolumn{2}{|c|}{ Fairly good $=1$} & \multicolumn{2}{|c|}{ Fairly bad $=2$} & \multicolumn{2}{|c|}{ Very bad $=3$} \\
\hline & Number & $\begin{array}{r}\text { Perce } \\
\text { nt }\end{array}$ & Number & $\begin{array}{r}\text { Perce } \\
\text { nt }\end{array}$ & Number & $\begin{array}{r}\text { Perce } \\
n t\end{array}$ & Number & $\begin{array}{r}\text { Perce } \\
\text { nt }\end{array}$ \\
\hline N-S & 15 & 32 & 17 & $36 / 1$ & 10 & $21 / 3$ & 5 & $10 / 6$ \\
\hline $\mathbf{S}-\mathbf{N}$ & 12 & $34 / 3$ & 12 & $34 / 3$ & 6 & $17 / 1$ & 5 & $14 / 3$ \\
\hline E-W & 11 & $27 / 5$ & 8 & 20 & 10 & 25 & 11 & $27 / 5$ \\
\hline W-E & 9 & 29 & 5 & $16 / 1$ & 6 & $19 / 4$ & 11 & $35 / 5$ \\
\hline Total & $\begin{array}{r}47(30.72 \\
\%)\end{array}$ & & $\begin{array}{r}42(27.45 \\
\%)\end{array}$ & & $\begin{array}{r}32(20.92 \\
\%)\end{array}$ & & $\begin{array}{r}32(20.92 \\
\%)\end{array}$ & \\
\hline
\end{tabular}

P> 0.05 $\mathrm{X}^{2}=12.1$

Table No 8: comparison the daytime drowsiness with geographical direction

\begin{tabular}{|c|c|c|c|c|c|c|c|c|}
\hline \multirow{2}{*}{$\begin{array}{r}\text { Directio } \\
\mathbf{n}\end{array}$} & \multicolumn{2}{|r|}{$0=$ None } & \multicolumn{2}{|c|}{$1=<1 /$ week } & \multicolumn{2}{|c|}{ 2=1-2/week } & \multicolumn{2}{|c|}{ 3= >3/week } \\
\hline & Number & $\begin{array}{r}\text { Percen } \\
\mathbf{t}\end{array}$ & Number & $\begin{array}{r}\text { Percen } \\
\mathbf{t}\end{array}$ & Number & $\begin{array}{r}\text { Percen } \\
\mathbf{t}\end{array}$ & $\begin{array}{r}\text { Numbe } \\
\mathbf{r}\end{array}$ & $\begin{array}{r}\text { Percen } \\
\mathbf{t}\end{array}$ \\
\hline $\mathrm{N}-\mathrm{S}$ & 12 & $25 / 5$ & 22 & $48 / 8$ & 9 & $19 / 2$ & 4 & $8 / 5$ \\
\hline $\mathbf{S}-\mathbf{N}$ & 9 & $25 / 7$ & 17 & $48 / 6$ & 6 & $17 / 1$ & 3 & $8 / 6$ \\
\hline E-W & 9 & $22 / 5$ & 18 & 45 & 10 & 25 & 3 & $7 / 5$ \\
\hline W-E & 10 & $32 / 3$ & 12 & $38 / 7$ & 6 & $19 / 3$ & 3 & $9 / 7$ \\
\hline Total & $\begin{array}{r}40(26.14 \\
\%)\end{array}$ & & $\begin{array}{r}69(45.1 \\
\%)\end{array}$ & & $\begin{array}{r}31(20.26 \\
\%)\end{array}$ & & $\begin{array}{r}13(8.5 \\
\%)\end{array}$ & \\
\hline
\end{tabular}

$\mathbf{P}>0.05 \quad X^{2}=1.76$

\section{CONCLUSION}

In order to study the impact of the geographical directions during sleep on the quality of sleep we conducted this study. There was significant relationship between difficulty of falling asleep and geographical direction $(\mathrm{p}<0.001)$, in the north-south sleep direction, the least sleep difficulty 
existed, and in the west- east the most. Similar studies in the area of the effect of the earth's magnetic field on the quality of sleep has not been done, so comparing the results of this study with other researches is not possible. Studies that can be somehow compared to the present study are: Study of Torbjorn and his colleagues and also Tworoger, creating artificial magnetic field, which had no effect on the structure of sleep (15-16). In this study Earth's magnetic field has been effective. Mesquita evaluated the role of stressor on the quality of sleep and concluded that stressors can make Sleep disorder (17). The present study has been conducted out of exams season in order to remove psychological pressure and according to SCL- 90-R, samples who were suffering from anxiety excluded. Chen and also James showed that the level of education could impact on sleep difficulty (18-19). Almost a similar study in this field has been done by Falarigna(222). In our study all the participants were university students, therefore education as a potential interfering factor was removed. Broun studied; type of job on the quality of sleep is important factor (23). In present study, all the participants were students (as a job) so, job's role as an agent excluded, (all courses were full- time) Physical disorder, as an important factor in creating disturbance in quantity and quality of sleep showed by Mc Namara (24). In this study, those had physical problems in recent month were excluded, so we can eliminate this factor. This point worth mentioning again, an exact similar research to this study has not been in the literature so we tried to compare almost similar researches and to remove the confounding variables as much as possible to survey real impact of geographical direction on the quality of sleeping process. Eventually based on the results of this study, sleep in north-south direction, means nearly to the earth's magnetic field direction, is the cause of better quality and less problem of sleep, so it can be recommended to add to sleep hygiene points.

Declaration of interest: None

\section{AUTHORS' CONTRIBUTION:}

SMM conceived and designed the study. MA and MBM participated in designing the evaluation, collecting data, performing the statistical analysis and revised the manuscript. JS re-evaluated the data and revised the manuscript. All authors read and approved the final manuscript.

\section{ACKNOWLEDGMENT}

The authors sincerely are grateful to, the vice chancellor of MUMS for financial support and all the students for participating in this study.

\section{REFERENCES}

Akerstedt T, Arnetz B, Ficca G, Paulsson LE, Kallner A. 50-Hz electromagnetic field impaired sleep .Journal of sleep Research .1999; 8(1):77-81.17- Tworoger SS, Davis S, Emerson 
SS, Mirick DK, Lentz MJ, McTiernman A. Effect of a Nighttime Magnetic field Exposure on sleep pattern is in young women.Am J Epidemiol.2004; 160(3):224-229.

Anders TF .Sleep disorder in infancy through adolescence .The American Psychiatric Publishing

Text book of child and Adolescent Psychiatry.2004;3(2):727-742.

Broun FC , Bubaltz W C,soper B .Sleep quality and morningness - eveningness of shift nurses .Journal of clinical Nursing.2008;18(1):279-28

Buysse DJ, Reynolds CF, Monk TH, Berman SR, Kupfer DJ. The Pittsburg Sleep Quality Index (PSQI): A new instrument for psychiatric reaserch and practice. Psychiatry research, 1989; 28(2),193-213.The detailed scoring instructions are at the end of this journal article.

Buysse DJ, Reynolds Iii CF, Monk TH, Berman SR, Kupfer DJ. The Pittsburgh sleep quality index: a new instrument for psychiatric practice and research. Psychiatry Res. 1989; 28: $193-213$.

chen PH. Kuo HY .Sleep hygiene education .Efficacy on sleep Quality in working women.2010;18(4)283-289.

Driver H. Sleep in women .Malvern sleep psychiatric. 2007; 1(3):1-2.

Falarigna Kleber FD, et al .sleep disorders among undergraduate student in southern Brazil .sleep disorders among undergraduate student in southern Brazil. sleep Breath.2010;2(2):375378.

Galland P .Magneto-reception in plants .Journal of plant Research.2005; 118(6):371-389.

Gegear R et al .Crypto chrome Mediates light -dependent magneto sensitivity .Drosophila Nature.2008; 454(7207):1014-1018.

Ivanenko A, Massey C. Assessment and Management of sleep Disorder in children. Psychiatric time.2006; 23(11):185-190

James F, pagel C F. Sleep complaints effecting school performance at different educational levels.2006, 115(1):249-251

Keshavarz A, Galebandi MF. Sleep quality \& it's correlation with general health in non-private pre- university students of Karaj. Iranian Journal of psychiatry and behavioral science.2009; 3(1):44-9 Revised.

Liu H, Chen G, Pan Y, Chen Z, Jin W, et al:(2014). Occupational Electromagnetic Field Exposures Associated with Sleep Quality: A cross-Sectional study.PLoS ONE 9(10):e 110825.doi:10.1371/Journal.pone.0110825

Mahowald M W. What is causing excessive daytime sleepiness .Evaluation to distinguish sleep deprivation from sleep disorder postgraduate Medicine. 2008; 107(3):108-123.

MC Namara D. Variance of occlusal support in temporomandibular pain and dysfunction patients . Journal Dent Reserch.2007; 61(2):350-351.

Mesquita G, Reima Reima R . Stress and Sleep quality in high school brazilian adolescents .An Acad Bras science.2010;82(2):542-551.

Meyer CG, Holland K. Sharks can detect changes in the geomagnetic field? Journal of the Royal society Interface.2005; 2(2):129-130.

Noorbala AA, Mohammad K, Bagheri Yazdi SA. A Survay of Psychiatric Disorders in Tehran City. Hakim Magazine. 1998;4:212-23. 
Prevalence and correlates of poor sleep quality and daytime sleepness in belgian truck drivers. Choronobiol Int. 2011;28(2):126-34.

Ruhenstroth-bauer $\mathrm{G}$ et al. Influence of the earth's Magnetic field on resting and activated EEG Mapping in normal subject .International Journal of Neuro science.1993;73(3):195-201.

Schneider D .safe and effective therapy for sleep problems in the older paitent.Geratrics.2002; 57(5):24-25.

Shurle BA, Arnett PA. Longitudinal study of Symptom Checklist 90 Revised. The Clinical Neuropsychologist. 2006;22:46-59.

Society for Neuroscience. Brain Activity During Sleep;2012. [Internet]. Available from http://www.brainfacts.org/sensing-thinking-behaving/sleep/articles/2012/brain-activityduring-sleep. [Cited 2015April11]. 